\title{
THIAMINE LOSSES DURING STORAGE OF PASTEURISED AND STERILIZED MODEL SYSTEMS OF MINCED CHICKEN MEAT WITH ADDITION OF FRESH AND OXIDIZED FAT, AND ANTIOXIDANTS*
}

\author{
Krystyna Szymandera-Buszka ${ }^{\bowtie}$, Marzanna Hęś, Katarzyna Waszkowiak, \\ Anna Jędrusek-Golińska
}

Department of Human Nutrition and Food Technology, Poznań University of Life Sciences Wojska Polskiego 31, 61-624 Poznań, Poland

\begin{abstract}
Background. The aim of the study was to determine the effect of pasteurisation and sterilization of model systems of minced chicken meat in the presence of low or high-oxidised pork lard, soy and sunflower oil, as well as casein hydrolysate and rosemary extract, on losses of thiamine in model systems.

Material and methods. In the samples, the thiamine content was analysed periodically by thiochromium method, as well as rate of lipid oxidation based on measurement of peroxide value (PV) by iodometric method and p-anisidine value (AV) by spectrophotometric method.

Results. It was observed that the thiamine losses in model systems of minced chicken after pasteurisation (61$-71 \%$ ) were higher than after sterilization (57-67\%). Introduction of high-oxidised fat increased the total thiamine losses both during thermal processing and storage of meat samples (to 23\%). A strong relationship was established between thiamine losses and rate of fat oxidation. The lowest total thiamine losses were observed in the samples with low-oxidised pork lard. Antioxidant addition (rosemary extract or casein hydrolysate) into meat samples limited the thiamine losses. However, the effect depended on oxidation of fat that was mixed with meat. In the samples with low-oxidised fat, higher protective effect was found for rosemary extract (7$-11 \%)$. In the samples with high-oxidised fat, casein hydrolysate was superior to rosemary extract (14\%).

Conclusions. In order to increase the stability of thiamine in pasteurized or sterilized meat products with fats, the influence of fat type and its oxidative stability should be taken under consideration. Moreover, the addition of rosemary extract or casein hydrolysate has impact on the thiamine losses since it slows down lipid oxidation to a significant extent.
\end{abstract}

Key words: thermal processing, chicken meat, thiamine, antioxidants

\section{INTRODUCTION}

Thiamine (vitamin $\mathrm{B}_{1}$ ) is a water-soluble compound which consists of a pyrimidine nucleus and a thiazole ring. Thiamine is widely distributed in plants and animal tissues and is found in high concentrations in yeast, beans, wheat germ, oats, meat, soy beans, and so on. The vitamin plays an important role as a coenzyme in the tricarboxylic acid cycle and in the hexose monophosphate shunt. Thiamine deficiency produces

*The research was financial supported by National Science Center in Poland (the project no. N312 241638). 

sterilized model systems of minced chicken meat with addition of fresh and oxidized fat, and antioxidants. Acta Sci. Pol., Technol. Aliment. 13(4), 393-401.

symptoms which are primarily located in heart and nerve tissues. These symptoms can be rapidly reversed by thiamine supplementation. Thiamine also plays an important role in neurotransmission, as well as several other key biochemical pathways [Johnson et al. 2002, Frank et al. 2007, Bettendorff and Wins 2009]. Besides amino acid composition, thiamine content is a crucial index of meat and meat product nutritive value. Previous studies showed that thermal processing causes great thiamine losses [Cooksey et al. 1990, Szymandera-Buszka and Waszkowiak 2003, Seidler et al. 2004, Szymandera-Buszka et al. 2006, Szymandera-Buszka 2012]. Moreover, products of lipid oxidation intensify the unfavourable heat effect to thiamine [Szymandera-Buszka 2003]. Taking into consideration the need to prolong storage time of meat products, lipid oxidation accelerated by the thermal processing gains much importance. The aim of the study was to determine the effect of thermal processing (pasteurisation and sterilization) and storage of model systems of minced chicken with fresh and oxidized fats (i.e. pork lard, soy and sunflower oils) and selected antioxidants on changes thiamine content. As the antioxidants casein hydrolysate and rosemary extract were applied.

\section{MATERIAL AND METHODS}

Materials. In the study, chicken meat (chicken breast) was the source of thiamine. The meat was previously minced (mesh size of $2 \mathrm{~mm}$ ) and then mixed with some additives:

- low-oxidised pork lard, soy oil or sunflower oil $\left(\mathrm{PV}=1.0 \pm 0.1 \mathrm{meq}_{2} \mathrm{~kg}^{-1}\right): 20 \mathrm{~g}$ per $80 \mathrm{~g}$ meat

- high-oxidised pork lard, soy oil or sunflower oil (the oxidation was carried out by incubation at $35^{\circ} \mathrm{C}$ up to $\mathrm{PV}=20 \pm 0.5$ meq $\left.\mathrm{O}_{2} \mathrm{~kg}^{-1}\right): 20 \mathrm{~g}$ per 80 g meat

- casein hydrolysate ("Winiary", Poland): 2 g per 100 g meat

- rosemary (Rosmarinus officinalis) ethanolic extract - obtained according to Korczak et al. [1990]: $20 \mathrm{mg}$ per $100 \mathrm{~g}$ meat.

After mixing with the above mentioned components, $100 \mathrm{~g}$ of meat samples was placed in painted black glass jars (with twist-off type cap; about $55 \mathrm{~mm}$ in diameter and volume of $170 \mathrm{~cm}^{3}$ ). The glass jars were closed under nitrogen. Pasteurisation was carried out at $100^{\circ} \mathrm{C}$ for $60 \mathrm{~min}$ (convection oven - RATIONAL AG). Sterilization was carried out at $121^{\circ} \mathrm{C}$ for $35 \mathrm{~min}$ (taking into account the time needed for heating up and cooling) in an autoclave. After thermal processing, the samples were stored for 6 months at $20-24^{\circ} \mathrm{C}$.

Determination of changes in thiamine contents and lipid oxidation. Thiamine content in chicken meat samples were determined before and after thermal processing, as well as periodically during their storage (every 30 days).

Total thiamine content. Total thiamine content was determined using the thiochromium method [Rettenmaier et al. 1979, Waszkowiak and Szymandera-Buszka 2007].

Free and bound thiamine content. Free thiamine content was determined using the thiochromium method [Waszkowiak and Szymandera-Buszka 2007] with some modifications as follows. A $15 \mathrm{~g}$ of meat sample was agitated (rotary shaker) for $15 \mathrm{~min}$ with $200 \mathrm{~mL}$ of $0.1 \mathrm{~mol} \mathrm{~L}^{-1}$ sulphuric acid and hydrolysed for $30 \mathrm{~min}$ at $95-100^{\circ} \mathrm{C}$ in boiling water with frequent mixing (rotary shaker). Then the sample was cooled down, diluted to $250 \mathrm{~mL}$ and filtered (filter paper). The next steps were carried out by the method of total thiamine. The amount of the bound thiamine was calculated from the difference between total thiamine and free one.

Lipid oxidation. Oxidative changes of lipid were analysed periodically (every 30 days) based on measurement of peroxide value (PV) by iodometric method [ISO 3960:2007] and p-anisidine value (AV) by spectrophotometric method [PN-EN ISO 6885:2001, Pérez-Palacios et al. 2008].

Statistical analysis. Statistical analyses were conducted using Statistica (version 9.0, StatSoft). Data were expressed as mean \pm standard deviation (SD) of three independent samples and three independent measurements for each sample $(n=9)$. The effect of treatment (pasteurisation and sterilization, $L=2$ ) and/or addition (three low or high-oxidised fats and two antioxidant or without antioxidant, $L=18$ ) was analysed. Analysis of variance (ANOVA) for a CRD (completely randomised design) experiment and then Tukey's multiple range test $(p \leq 0.05)$ was applied to compare the means. For analyses of thiamine changes during storage, the correlations between variables were established using the regression analysis. 
Szymandera-Buszka K., Hęś M., Waszkowiak K., Jędrusek-Golińska A., 2014. Thiamine losses during storage of pasteurised and sterilized model systems of minced chicken meat with addition of fresh and oxidized fat, and antioxidants. Acta Sci. Pol., Technol. Aliment. 13(4), 393-401.

To compare the dynamics of occurring changes, time $t_{(1 / 2)}$ was determined, in which the initial thiamine content decreases by half.

\section{RESULTS}

\section{Changes in thiamine content after thermal processing}

The analyses of thiamine changes after thermal processes showed that they caused high losses of both free and bound thiamine forms probably by disrupting thiazole ring. It supports the results of the previous studies [Szymandera-Buszka 2003]. The pasteurisation caused higher total thiamine losses when compared to sterilization (Table 1). The total thiamine losses in meat samples after pasteurisation ranged from $61 \%$ to $71 \%$ and were lower by 4 percentage points than those after sterilization.

The addition of low-oxidised fat into chicken meat did not increase the total thiamine losses during the thermal processing, when compared to losses in the samples without fat addition (the results are not

Table 1. Thiamine losses during pasteurisation and sterilization chicken meat with fresh and oxidised fat and selected antioxidants, $\%$

\begin{tabular}{|c|c|c|c|c|c|c|c|}
\hline \multicolumn{2}{|c|}{ Addition } & \multicolumn{6}{|c|}{ Thiamine } \\
\hline \multirow{2}{*}{ fat } & \multirow{2}{*}{ antioxidant } & \multicolumn{2}{|c|}{ total } & \multicolumn{2}{|c|}{ free } & \multicolumn{2}{|c|}{ bound } \\
\hline & & $\mu \mathrm{g} / 100 \mathrm{~g}$ & $\%$ & $\mu \mathrm{g} / 100 \mathrm{~g}$ & $\%$ & $\mu \mathrm{g} / 100 \mathrm{~g}$ & $\%$ \\
\hline 1 & 2 & 3 & 4 & 5 & 6 & 7 & 8 \\
\hline \multicolumn{8}{|c|}{ Pasteurisation } \\
\hline \multicolumn{8}{|l|}{ Pork lard } \\
\hline fresh & without & $26.082^{\mathrm{b}, \mathrm{a}, \mathrm{B}^{*}}$ & 62.2 & $27.600^{\mathrm{b}, \mathrm{a}, \mathrm{B}}$ & 60.0 & $23.322^{\mathrm{b}, \mathrm{a}, \mathrm{B}}$ & 66.2 \\
\hline \multirow{5}{*}{ oxidised } & casein hydrolysate & $26.841^{\mathrm{a}, \mathrm{B}}$ & 61.1 & $28.221^{\mathrm{a}, \mathrm{B}}$ & 59.1 & $24.081^{\mathrm{a}, \mathrm{B}}$ & 65.1 \\
\hline & rosemary extract & $26.358^{\mathrm{b}, \mathrm{a}, \mathrm{B}}$ & 61.8 & $27.807^{\mathrm{b}, \mathrm{a}, \mathrm{B}}$ & 59.7 & $23.736^{\mathrm{a}, \mathrm{B}}$ & 65.6 \\
\hline & without & $23.115^{\mathrm{h}, \mathrm{g}, \mathrm{f}, \mathrm{B}}$ & 66.5 & $24.495^{\mathrm{i}, \mathrm{h}, \mathrm{B}}$ & 64.5 & $19.113^{\mathrm{g}, \mathrm{f}, \mathrm{B}}$ & 72.3 \\
\hline & casein hydrolysate & $25.530^{\mathrm{c}, \mathrm{b}, \mathrm{B}}$ & 63.0 & $26.841^{\mathrm{d}, \mathrm{c}, \mathrm{B}}$ & 61.1 & $21.528^{\mathrm{c}, \mathrm{b}, \mathrm{B}}$ & 68.8 \\
\hline & rosemary extract & $23.598^{\mathrm{f}, \mathrm{B}}$ & 65.8 & $24.978^{\mathrm{h}, \mathrm{g}, \mathrm{B}}$ & 63.8 & $19.596^{\mathrm{fe, \textrm {B }}}$ & 71.6 \\
\hline \multicolumn{8}{|l|}{ Soy oil } \\
\hline \multirow[t]{3}{*}{ fresh } & without & $25.668^{c, b, B}$ & 62.8 & $27.048^{c, b, B}$ & 60.8 & $23.046^{\mathrm{b}, \mathrm{B}}$ & 66.6 \\
\hline & casein hydrolysate & $26.220^{\mathrm{b}, \mathrm{a}, \mathrm{B}}$ & 62.0 & $27.600^{\mathrm{b}, \mathrm{a}, \mathrm{B}}$ & 60.0 & $23.736^{\mathrm{a}, \mathrm{B}}$ & 65.6 \\
\hline & rosemary extract & $25.737^{\mathrm{c}, \mathrm{b}, \mathrm{B}}$ & 62.7 & $27.117^{\mathrm{c}, \mathrm{b}, \mathrm{B}}$ & 60.7 & $23.184^{\mathrm{b}, \mathrm{a}, \mathrm{B}}$ & 66.4 \\
\hline \multirow[t]{3}{*}{ oxidised } & without & $20.355^{\mathrm{i}, \mathrm{B}}$ & 70.5 & $23.322^{\mathrm{j}, \mathrm{B}}$ & 66.2 & $18.185^{\mathrm{h}, \mathrm{B}}$ & 73.5 \\
\hline & casein hydrolysate & $24.150^{\mathrm{fe}, \mathrm{B}}$ & 65.0 & $25.323^{\mathrm{g}, \mathrm{B}}$ & 63.3 & $20.010^{\mathrm{e}, \mathrm{B}}$ & 71.0 \\
\hline & rosemary extract & $23.115^{\mathrm{h}, \mathrm{g}, \mathrm{f}, \mathrm{B}}$ & 66.5 & $24.495^{\mathrm{h}, \mathrm{B}}$ & 64.5 & $19.113^{\mathrm{g}, \mathrm{f}, \mathrm{B}}$ & 72.3 \\
\hline \multicolumn{8}{|c|}{ Sunflower oil } \\
\hline \multirow[t]{3}{*}{ fresh } & without & $25.254^{\mathrm{d}, \mathrm{c}, \mathrm{B}}$ & 63.4 & $26.496^{\mathrm{e}, \mathrm{d}, \mathrm{B}}$ & 61.6 & $22.632^{\mathrm{d}, \mathrm{c}, \mathrm{b}, \mathrm{B}}$ & 67.2 \\
\hline & casein hydrolysate & $26.496^{\mathrm{b}, \mathrm{a}, \mathrm{B}}$ & 61.6 & $26.496^{\mathrm{e}, \mathrm{d}, \mathrm{B}}$ & 59.6 & $23.874^{\mathrm{a}, \mathrm{B}}$ & 65.4 \\
\hline & rosemary extract & $25.185^{\mathrm{d}, \mathrm{c}, \mathrm{B}}$ & 63.5 & $26.565^{\mathrm{e}, \mathrm{d}, \mathrm{B}}$ & 61.5 & $22.563^{\mathrm{d}, \mathrm{c}, \mathrm{b}, \mathrm{B}}$ & 67.3 \\
\hline \multirow[t]{3}{*}{ oxidised } & without & $22.839^{\mathrm{h}, \mathrm{g}, \mathrm{B}}$ & 66.9 & $24.081^{\mathrm{i}, \mathrm{B}}$ & 65.1 & $18.837^{\mathrm{h}, \mathrm{g}, \mathrm{B}}$ & 72.7 \\
\hline & casein hydrolysate & $24.840^{\mathrm{e}, \mathrm{d}, \mathrm{B}}$ & 64.0 & $26.220^{\mathrm{f}, \mathrm{e}, \mathrm{d}, \mathrm{B}}$ & 62.0 & $20.838^{\mathrm{d}, \mathrm{c}, \mathrm{B}}$ & 69.8 \\
\hline & rosemary extract & $23.460^{\mathrm{g}, \mathrm{f}, \mathrm{B}}$ & 66.0 & $24.771^{\mathrm{h}, \mathrm{g}, \mathrm{B}}$ & 64.1 & $19.458^{\mathrm{f}, \mathrm{e}, \mathrm{B}}$ & 71.8 \\
\hline
\end{tabular}


Szymandera-Buszka K., Hęś M., Waszkowiak K., Jędrusek-Golińska A., 2014. Thiamine losses during storage of pasteurised and sterilized model systems of minced chicken meat with addition of fresh and oxidized fat, and antioxidants. Acta Sci. Pol., Technol. Aliment. 13(4), 393-401.

Table 1 - cont.

\begin{tabular}{|c|c|c|c|c|c|c|c|}
\hline 1 & 2 & 3 & 4 & 5 & 6 & 7 & 8 \\
\hline \multicolumn{8}{|c|}{ Sterilization } \\
\hline \multicolumn{8}{|l|}{ Pork lard } \\
\hline fresh & without & $28.842^{\mathrm{b}, \mathrm{a}, \mathrm{A}}$ & 58.2 & $30.084^{\mathrm{c}, \mathrm{b}, \mathrm{A}}$ & 56.4 & $25.116^{\mathrm{c}, \mathrm{b}, \mathrm{a}, \mathrm{A}}$ & 63.6 \\
\hline \multirow{5}{*}{ oxidised } & casein hydrolysate & $29.670^{\mathrm{a}, \mathrm{A}}$ & 57.0 & $30.922^{\mathrm{b}, \mathrm{a}, \mathrm{A}}$ & 55.2 & $26.013^{\mathrm{a}, \mathrm{A}}$ & 62.3 \\
\hline & rosemary extract & $28.704^{\mathrm{b}, \mathrm{a}, \mathrm{A}}$ & 58.4 & $29.946^{\mathrm{d}, \mathrm{c}, \mathrm{A}}$ & 56.6 & $25.254^{\mathrm{b}, \mathrm{a}, \mathrm{A}}$ & 63.4 \\
\hline & without & $24.909^{\mathrm{h}, \mathrm{A}}$ & 63.9 & $26.080^{\mathrm{h}, \mathrm{g}, \mathrm{A}}$ & 62.2 & $20.907^{\mathrm{h}, \mathrm{A}}$ & 69.7 \\
\hline & casein hydrolysate & $27.807^{\mathrm{e}, \mathrm{d}, \mathrm{A}}$ & 59.7 & $28.980^{\mathrm{e}, \mathrm{A}}$ & 58.0 & $23.805^{\mathrm{e}, \mathrm{d}, \mathrm{A}}$ & 65.5 \\
\hline & rosemary extract & $25.668^{\mathrm{g}, \mathrm{A}}$ & 62.8 & $26.910^{\mathrm{g}, \mathrm{f}, \mathrm{A}}$ & 61.0 & $21.666^{\mathrm{g}, \mathrm{f,A}}$ & 68.6 \\
\hline \multicolumn{8}{|l|}{ Soy oil } \\
\hline \multirow[t]{3}{*}{ fresh } & without & $28.359^{\mathrm{d}, \mathrm{c}, \mathrm{b}, \mathrm{A}}$ & 58.9 & $29.601^{\mathrm{e}, \mathrm{d}, \mathrm{A}}$ & 57.1 & $24.357^{\mathrm{d}, \mathrm{c}, \mathrm{A}}$ & 64.7 \\
\hline & casein hydrolysate & $29.325^{\mathrm{a}, \mathrm{A}}$ & 57.5 & $30.360^{\mathrm{c}, \mathrm{b}, \mathrm{A}}$ & 56.0 & $25.323^{\mathrm{b}, \mathrm{a}, \mathrm{A}}$ & 63.3 \\
\hline & rosemary extract & $29.394^{\mathrm{a}, \mathrm{A}}$ & 57.4 & $30.360^{\mathrm{c}, \mathrm{b}, \mathrm{A}}$ & 56.0 & $25.392^{\mathrm{b}, \mathrm{a}, \mathrm{A}}$ & 63.2 \\
\hline \multirow[t]{3}{*}{ oxidised } & without & $22.908^{\mathrm{j}, \mathrm{A}}$ & 66.8 & $24.150^{\mathrm{i}, \mathrm{A}}$ & 65.0 & $19.320^{\mathrm{k}, \mathrm{A}}$ & 72.0 \\
\hline & casein hydrolysate & $25.668^{\mathrm{g}, \mathrm{A}}$ & 62.8 & $26.841^{\mathrm{g}, \mathrm{f}, \mathrm{A}}$ & 61.1 & $21.597^{\mathrm{g}, \mathrm{A}}$ & 68.7 \\
\hline & rosemary extract & $24.150^{\mathrm{i}, \mathrm{A}}$ & 65.0 & $25.323^{\mathrm{i}, \mathrm{A}}$ & 63.3 & $20.079^{\mathrm{j}, \mathrm{I}, \mathrm{A}}$ & 70.9 \\
\hline \multicolumn{8}{|c|}{ Sunflower oil } \\
\hline \multirow[t]{3}{*}{ fresh } & without & $28.566^{\mathrm{c}, \mathrm{b}, \mathrm{A}}$ & 58.6 & $29.808^{\mathrm{d}, \mathrm{c}, \mathrm{A}}$ & 56.8 & $24.564^{\mathrm{d}, \mathrm{c}, \mathrm{b}, \mathrm{A}}$ & 64.4 \\
\hline & casein hydrolysate & $29.187^{\mathrm{b}, \mathrm{a}, \mathrm{A}}$ & 57.7 & $31.050^{\mathrm{a}, \mathrm{A}}$ & 55.0 & $25.944^{\mathrm{a}, \mathrm{A}}$ & 62.4 \\
\hline & rosemary extract & $28.635^{\mathrm{c}, \mathrm{b}, \mathrm{A}}$ & 58.5 & $29.877^{\mathrm{d}, \mathrm{c}, \mathrm{b}, \mathrm{A}}$ & 56.7 & $24.564^{\mathrm{d}, \mathrm{c}, \mathrm{A}}$ & 64.4 \\
\hline \multirow[t]{3}{*}{ oxidised } & without & $24.840^{\mathrm{h}, \mathrm{A}}$ & 64.0 & $25.944^{\mathrm{i}, \mathrm{h}, \mathrm{A}}$ & 62.4 & $20.700^{\mathrm{i}, \mathrm{h}, \mathrm{A}}$ & 70.0 \\
\hline & casein hydrolysate & $26.358^{\mathrm{f}, \mathrm{A}}$ & 61.8 & $27.462^{\mathrm{f}, \mathrm{A}}$ & 60.2 & $22.356^{\mathrm{f}, \mathrm{A}}$ & 67.6 \\
\hline & rosemary extract & $24.978^{\mathrm{h}, \mathrm{A}}$ & 63.8 & $26.151^{\mathrm{h}, \mathrm{g}, \mathrm{A}}$ & 62.1 & $20.907^{\mathrm{h}, \mathrm{A}}$ & 69.7 \\
\hline
\end{tabular}

*Different letters denote a significant difference for means (means followed by different small letter correspond to type of addition are significantly different at $p \leq 0.05$; means followed by different capital letter correspond to type of thermal processing "pasteurisation and sterilization' are significantly different at $p \leq 0.05$ ).

shown). The total thiamine losses were also not affected by type of fat that was added to the samples. However, introduction of high-oxidised fat into meat samples increased the total thiamine losses, both after pasteurisation and sterilization. Higher thiamine losses were found after thermal processing of the samples with high-oxidised soy oil than the ones with high-oxidised sunflower oil. The lowest losses of total thiamine were observed for the meat samples with high-oxidised pork lard.

The addition of casein hydrolysate to the samples with low-oxidised fat lowered the bound thiamine losses by 1-2 percentage points, both after pasteurisation and sterilization. The rosemary extract addition to the samples with high-oxidised oil lowered the loss of bound thiamine by 2 percentage points, however, casein hydrolysate caused lowering thiamine losses by 2-4 percentage points.

The thiamine losses during thermal processing depended on thiamine form. The losses of bound thiamine were higher by 5 percentage points when compared to free thiamine form. The relationship between rate of fat oxidation and bound thiamine losses were observed. Higher losses of bound thiamine (at about 8 percentage points) were observed in the samples with high-oxidised fats. 


\section{Changes in thiamine content during storage}

During meat samples storage, further increases in lipid oxidation and also thiamine losses were recorded. The high correlation between values of oxidation indexes and thiamine contents in stored meat samples was observed (Table 4). The highest dynamics of thiamine changes was found in the samples with addition of high-oxidised soy oil in which the highest values of $\mathrm{PV}$ and $\mathrm{AV}$ were observed (the results are not shown). Calculated thiamine half-life of sterilized or pasteurised meat samples with high-oxidised soy oil was the shortest and amounted to 403 and 400 days, respectively. It was lower by about $20 \%$ than half-life of the samples with low-oxidised fats.
The antioxidant addition, i.e. rosemary extract or casein hydrolysate, to meat samples limited the thiamine losses. However, the effect depended on oxidation of fat that was mixed into chicken meat. The highest protective effect of rosemary extract on thiamine was observed in meat samples with low-oxidised fat (Table 2). The longest half-life was found in the stored samples with low-oxidised pork lard and rosemary extract. In the samples with high-oxidised fat, casein hydrolysate was superior to rosemary extract addition (Table 3). Application of casein hydrolysate and rosemary extract extended the half-life of the stored meat samples with high-oxidised fats at about $15 \%$ and $4 \%$, respectively, comparing with the samples without the addition.

Table 2. Dynamics of total thiamine losses (time $t_{1 / 2}$, days) during storage of pasteurised and sterilized chicken meat with low-oxidised fat and selected antioxidants

\begin{tabular}{|c|c|c|c|c|}
\hline \multirow{2}{*}{ Thermal processing } & \multicolumn{2}{|c|}{ Addition } & \multicolumn{2}{|c|}{$\begin{array}{c}\text { Dynamic of total thiamine } \\
\text { changes }\end{array}$} \\
\hline & fat & antioxidant & $t_{1 / 2}$, days & $R^{2}$ \\
\hline \multirow[t]{9}{*}{ Pasteurisation } & pork lard & without the addition & $528^{\mathrm{d}}$ & 0.988 \\
\hline & & casein hydrolysate & $552^{\mathrm{h}}$ & 0.967 \\
\hline & & rosemary extract & $583^{1}$ & 0.968 \\
\hline & soy oil & without the addition & $509^{\mathrm{a}}$ & 0.974 \\
\hline & & casein hydrolysate & $551^{\mathrm{h}}$ & 0.986 \\
\hline & & rosemary extract & $549^{\mathrm{g}}$ & 0.991 \\
\hline & sunflower oil & without the addition & $517^{\mathrm{b}}$ & 0.987 \\
\hline & & casein hydrolysate & $542^{\mathrm{e}}$ & 0.912 \\
\hline & & rosemary extract & $569^{k}$ & 0.950 \\
\hline \multirow[t]{9}{*}{ Sterilization } & pork lard & without the addition & $523^{\mathrm{c}}$ & 0.941 \\
\hline & & casein hydrolysate & $546^{\mathrm{f}}$ & 0.956 \\
\hline & & rosemary extract & $582^{1}$ & 0.899 \\
\hline & soy oil & without the addition & $510^{\mathrm{a}}$ & 0.950 \\
\hline & & casein hydrolysate & $549^{\mathrm{g}}$ & 0.974 \\
\hline & & rosemary extract & $566^{\mathrm{j}}$ & 0.944 \\
\hline & sunflower oil & without the addition & $514^{\mathrm{b}}$ & 0.989 \\
\hline & & casein hydrolysate & $560^{\mathrm{i}}$ & 0.977 \\
\hline & & rosemary extract & $570^{\mathrm{k}}$ & 0.989 \\
\hline
\end{tabular}

$t_{1 / 2}$, days - time in which the initial thiamine content decreases by half.

$R^{2}$ - coefficient for simple linear regression.

Different letters denote a significant difference for means significantly different at $p \leq 0.05$. 
Szymandera-Buszka K., Hęś M., Waszkowiak K., Jędrusek-Golińska A., 2014. Thiamine losses during storage of pasteurised and sterilized model systems of minced chicken meat with addition of fresh and oxidized fat, and antioxidants. Acta Sci. Pol., Technol. Aliment. 13(4), 393-401.

Table 3. Dynamics of total thiamine losses (time $t_{1 / 2}$, days) during storage of pasteurised and sterilized chicken meat with high-oxidised fat and selected antioxidants

\begin{tabular}{|c|c|c|c|c|}
\hline \multirow[t]{2}{*}{ Thermal processing } & \multicolumn{2}{|r|}{ Addition } & \multicolumn{2}{|c|}{$\begin{array}{c}\text { Dynamic of total thiamine } \\
\text { changes }\end{array}$} \\
\hline & fat & antioxidant & $t_{1 / 2}$, days & $R^{2}$ \\
\hline \multirow[t]{9}{*}{ Pasteurisation } & pork lard & without & $429^{\mathrm{g}}$ & 0.903 \\
\hline & & casein hydrolysate & $480^{\mathrm{m}}$ & 0.876 \\
\hline & & rosemary extract & $450^{k}$ & 0.877 \\
\hline & soy oil & without & $400^{\mathrm{a}}$ & 0.939 \\
\hline & & casein hydrolysate & $460^{1}$ & 0.928 \\
\hline & & rosemary extract & $420^{\mathrm{e}}$ & 0.984 \\
\hline & sunflower oil & without & $414^{\mathrm{d}}$ & 0.937 \\
\hline & & casein hydrolysate & $472^{1}$ & 0.892 \\
\hline & & rosemary extract & $439 j$ & 0.928 \\
\hline \multirow[t]{9}{*}{ Sterilization } & pork lard & without & $431^{\mathrm{h}}$ & 0.952 \\
\hline & & casein hydrolysate & $494^{\mathrm{n}}$ & 0.899 \\
\hline & & rosemary extract & $451^{\mathrm{k}}$ & 0.975 \\
\hline & soy oil & without & $403^{b}$ & 0.959 \\
\hline & & casein hydrolysate & $460^{1}$ & 0.966 \\
\hline & & rosemary extract & $423^{\mathrm{f}}$ & 0.947 \\
\hline & sunflower oil & without & $416^{\mathrm{e}}$ & 0.968 \\
\hline & & casein hydrolysate & $478^{\mathrm{m}}$ & 0.966 \\
\hline & & rosemary extract & $436^{\mathrm{i}}$ & 0.956 \\
\hline
\end{tabular}

$t_{1 / 2}$, days - time in which the initial thiamine content decreases by half.

$R^{2}$ - coefficient for simple linear regression.

Different letters denote a significant difference for means significantly different at $p \leq 0.05$.

\section{DISCUSSION}

Pervious studies showed that thermal destruction of thiamine follows first order reaction kinetics [Mulley et al. 1975]. The thermal degradation of thiamine produces a number of compounds with particularly potent aromas, including furans, furanthiols, thiophenes, thiazoles, and aliphatic sulphur compounds, some of which have been reported in meat volatiles [Mottram 1991]. During thermal processing, thiamine retention is determined by the type of heating medium and time of thermal processing [Mulley et al. 1975, Waszkowiak et al. 1999, Szymandera-Buszka 2003, Waszkowiak and Szymandera-Buszka 2007]. Results of the study showed that addition of high-oxidised fats to the chicken meat caused higher total thiamine losses, when compared to the meat samples with the low-oxidised fats addition, after the thermal processing. During storage of the samples further increase of lipid oxidation and thiamine losses were recorded. Thiamine losses in the meat samples with highoxidised fats resulted from the thiamine sensibility to oxidation and reduction factors [Dwivedi and Arnold 1972]. Similar results were obtained during pork sterilization [Szymandera-Buszka 2003]. Higher losses of thiamine in the presence of oils than pork lard were probably connected with the difference in oxidative stability of the applied fats. In the study it was also 
Szymandera-Buszka K., Hęś M., Waszkowiak K., Jędrusek-Golińska A., 2014. Thiamine losses during storage of pasteurised and sterilized model systems of minced chicken meat with addition of fresh and oxidized fat, and antioxidants. Acta Sci. Pol., Technol. Aliment. 13(4), 393-401.

Table 4. Relationship between total thiamine content and fat oxidation during storage of pasteurised and sterilized chicken meat with fresh and oxidised fat and selected antioxidants

\begin{tabular}{|c|c|c|c|c|}
\hline \multirow{2}{*}{ Thermal processing } & \multicolumn{2}{|c|}{ Addition } & \multicolumn{2}{|c|}{ Correlation coefficient } \\
\hline & fat & antioxidant & anisidine value & peroxide value \\
\hline \multirow[t]{9}{*}{ Pasteurisation } & pork lard & without & $0.917^{* * * *}$ & $0.856^{* * * *}$ \\
\hline & & casein hydrolysate & $0.811^{* * *}$ & $0.749^{* * *}$ \\
\hline & & rosemary extract & $0.896^{* * * *}$ & $0.865^{* * * *}$ \\
\hline & soy oil & without the addition & $0.908^{* * * *}$ & $0.871^{* * * *}$ \\
\hline & & casein hydrolysate & $0.795^{* * *}$ & $0.690^{* * *}$ \\
\hline & & rosemary extract & $0.909^{* * * *}$ & $0.859^{* * * *}$ \\
\hline & sunflower oil & without & $0.924^{* * * *}$ & $0.886^{* * * *}$ \\
\hline & & casein hydrolysate & $0.735^{* * *}$ & $0.682^{* * *}$ \\
\hline & & rosemary extract & $0.895^{* * * *}$ & $0.870^{* * * *}$ \\
\hline \multirow[t]{9}{*}{ Sterilization } & pork lard & without & $0.897^{* * * *}$ & $0.856^{* * * *}$ \\
\hline & & casein hydrolysate & $0.740^{* * *}$ & $0.724^{* * *}$ \\
\hline & & rosemary extract & $0.912^{* * * *}$ & $0.872^{* * * * *}$ \\
\hline & soy oil & without & $0.909^{* * * *}$ & $0.888^{* * * *}$ \\
\hline & & casein hydrolysate & $0.756^{* * *}$ & $0.694^{* * *}$ \\
\hline & & rosemary extract & $0.894^{* * * *}$ & $0.856^{* * * *}$ \\
\hline & sunflower oil & without & $0.924^{* * * *}$ & $0.884^{* * * *}$ \\
\hline & & casein hydrolysate & $0.795^{* * *}$ & $0.738^{* * *}$ \\
\hline & & rosemary extract & $0.909^{* * * *}$ & $0.859^{* * * *}$ \\
\hline
\end{tabular}

$p \leq 0.05 ; *$ linear, but low, $* *$ moderate linear correlation, $* * *$ strong linear relationship, $* * * *$ very strong linear relationship.

found that addition of rosemary extract and casein hydrolysate to chicken meat samples limited the thiamine losses. The protective effect of rosemary extract to thiamine, that was demonstrated in the study, can be explained by its antioxidant properties. The inhibition of lipid oxidation by rosemary extract was previously proved [Waszkowiak and Dolata 2007, Casarotti and Jorge 2012]. However, the results of our study demonstrated that casein hydrolysate had higher protective effect to thiamine than rosemary extract in stored meat samples with high-oxidised fats. Protective effect of casein hydrolysate to thiamine was previously demonstrated after sterilization of mixture contained pork and oxidised lard and casein hydrolysate [Szymandera-Buszka 2003]. The phenomenon seems to be an effect of reaction that occurs between oxidation products and amino acid residues of the hydrolysate. Because of those interactions, peptides and amino acids are suggested to partially protect of thiamine from oxidation-induced damage in presence oxidised fats. Results of earlier studies support the abovemaintained hypothesis showing that some proteins in food protect thiamine and $\mathrm{SH}$ groups are involved in it [Leichter and Joslyn 1969, Janitz and Czyżewska 1983, Skjöldebrand et al. 1983].

\section{CONCLUSION}

The thiamine losses in chicken meat were higher after pasteurisation than sterilization. The relationship was found between fat oxidation and thiamine losses. Addition of high-oxidised fat accelerated the total 
Szymandera-Buszka K., Hęś M., Waszkowiak K., Jędrusek-Golińska A., 2014. Thiamine losses during storage of pasteurised and sterilized model systems of minced chicken meat with addition of fresh and oxidized fat, and antioxidants. Acta Sci. Pol., Technol. Aliment. 13(4), 393-401.

thiamine losses, when compared to low-oxidised fat, both after thermal processing and storage of chicken meat. Addition of antioxidants (i.e. rosemary extract or casein hydrolysate) to meat samples limited the thiamine losses. Comparing the protective action of both antioxidants to thiamine, higher effect of rosemary extract was found in meat samples with low-oxidised fat. However, casein hydrolysate was superior to rosemary extracts in the samples with high-oxidised fat. Further investigations should be carried on to explain the phenomena.

\section{REFERENCES}

Bettendorff L., Wins P., 2009. Thiamine diphosphate in biological chemistry: new aspects of thiamin metabolism, especially triphosphate derivatives action other than as cofactors. FEBS J. 276, 2917-2925.

Casarotti S.N., Jorge N., 2012. Antioxidant activity of rosemary extract on soybean oil and thermoxidation. J. Food Proc. Preserv. DOI: 10.1111/j. 1745-4549.2012.00755.x.

Cooksey K., Klein B.P., Mc Keith F.K., 1990. Thiamin retention and other characteristics of cooked beef loin roasts. J. Food Sci. 55, 863-864.

Dwivedi B.K., Arnold R.G., 1972. Chemistry of thiamine degradation 4-methyl-S( $\beta$-hydroksyethyl) thiazole from thermally degradet thiamine. J. Food Sci. 37, 689-692.

Frank R.A.W., Leeper F.J., Luisi B.F., 2007. Structure, mechanism and catalytic duality of thiamine-dependent enzymes. Cell Mol. Life Sci. 64, 892-905.

ISO 3960:2007 (corrected version, 2009). Animal and vegetable oils and fats. Determination of peroxide value.

Janitz W., Czyżewska S., 1983. Thermischer Abbau des freien Thiamins im Schweinefleisch bei Vorhandensein technologischer Zusätze und Schwefelaminosäuren. Fleischwirtschaft 63, 1761-1765.

Johnson K.A., Bernard M.A., Funderburg K., 2002. Vitamin nutrition in older adults. Clin. Geriatr. Med. 18, 773-799.

Korczak J., Pazoła Z., Gogolewski M., 1990. Antioxidant properties of herbal spices from Labiatae family. I. Evaluation of antioxidatave activity in model systems. Vintage Books, AR, Poznań [in Polish].

Leichter J., Joslyn M., 1969. Protective effect of casein of the cleavage of thiamine by sulfite. J. Agric. Food Chem. 17, 1355-1359.

Mott Mottram D.S., 1991. Meat. In: Volatile compounds in foods and beverages. Ed. Hank Maarse. Marcell Dekker New York, 107-177.
Mulley E.A., Stumbo C.R., Hunting W.M., 1975. Thiamine: a chemical index of the sterilization efficacy of thermal processing. J. Food Sci. 40 (5), 993-996.

Pérez-Palacios T., Ruiz J., Martín D., Muriel E., Antequera T., 2008. Comparison of different methods for total lipid quantification in meat and meat products. Food Chem. 110 (4), 1025-1029.

PN-EN ISO 6885:2001. Oznaczanie liczby anizydynowej [Determination of anisidine value; in Polish].

Rettenmaier R., Vuilleumier J.P., Müller-Mulot W., 1979. Zur quantitativen Vitamin- $\mathrm{B}_{1}$ - Bestimmung in Nahrungsmitteln und biolgischem Material. Z. Lebensm. Unteres- Forsch 168, 120.

Ribeiro D., Pinto D., Lima L.M., Volpato N., Lúcio M., Cabral L.M., Sousa V., 2011. Chemical stability study of vitamins thiamine, riboflavin, pyridoxine and ascorbic acid in parenteral nutrition for neonatal use. Nutr. J. 10, 47.

Skjöldebrand C., Ånäs A., Öste R., Sjödin P., 1983. Prediction of thiamine content in convective heated meat products. Int. J. Food Sci. Techn. 18, 61-73.

Seidler T., Carnovale E., Lucarini G., Incerti I., 2004. Effect of conventional and HTST sterilization on thiamine and riboflavin content in salmon and hake canned products. Acta Sci. Pol., Technol. Aliment. 3 (2), 45-56.

Szymandera-Buszka K., 2012. Effect of soy and sunflower oil and selected antioxidants on quantitative and qualitative changes in thiamine in chicken meat during pasteurization and sterilization. The $2^{\text {nd }}$ International Vitamin Conference (Copenhagen, Denmark, 23-25.05.2012).

Szymandera-Buszka K., 2003. Quantitative and qualitative changes of thiamine in sterilized pork in the presence of selected technological additives. Polish J. Food Nutr. Sci. 12/53 (4), 59-62.

Szymandera-Buszka K., Górecka D., Hęś M., Waszkowiak K., 2006. Influence of cooking barley groats on the stability of thiamine. Polish J. Environ. Stud. 15 (2a), 835-837.

Szymandera-Buszka K., Waszkowiak K., Hęś M., Jędrusek-Golińska A., 2011. The effect of the application of protein and cellulose preparations as iodine carriers on stability of thiamine in processed meats. Nauka Przyr. Technol. 5, 1-10.

Szymandera-Buszka K., Waszkowiak K., 2003. Qualitative and quantitative changes of thiamine in turkey meatballs in the presence of potassium iodide. Acta Sci. Pol., Technol. Aliment. 2 (2), 95-101.

Waszkowiak K., Dolata W., 2007. The application of collagen preparations as carriers of rosemary extract in the production of processed meat. Meat Sci. 75 (1), 178-183. 
Szymandera-Buszka K., Hęś M., Waszkowiak K., Jędrusek-Golińska A., 2014. Thiamine losses during storage of pasteurised and sterilized model systems of minced chicken meat with addition of fresh and oxidized fat, and antioxidants. Acta Sci. Pol., Technol. Aliment. 13(4), 393-401.

Waszkowiak K., Szymandera-Buszka K., Janitz W., Górecka D., 1999. Comparative evaluation of nutrie and sensory value of selected raw materials and dishes after thermal processing in a convection oven and with conventional methods. EJPAU Food Sci. Techn. 2(2).
Waszkowiak K., Szymandera-Buszka K., 2007. Effect of collagen preparation used as carriers of potassium iodide on retention of iodine and thiamine during cooking and storage of pork meatballs. J. Sci. Food Agric. 87 (8), $1473-1479$

\section{STRATY TIAMINY PODCZAS PRZECHOWYWANIA PASTERYZOWANYCH I STERYLIZOWANYCH MODELOWYCH UKŁADÓW MIELONEGO MIĘSA DROBIOWEGO Z DODATKIEM ŚWIEŻEGO I UTLENIONEGO TKUSZCZU ORAZ PRZECIWUTLENIACZY}

\section{STRESZCZENIE}

Wstęp. Celem pracy było określenie wpływu pasteryzacji i sterylizacji modelowych układów mielonego mięsa drobiowego z dodatkiem świeżego i utlenionego tłuszczu (smalcu, oleju sojowego i słonecznikowego) oraz hydrolizatu kazeiny i ekstraktu rozmarynu na zmiany ilościowe i jakościowe tiaminy.

Materiał i metody. W próbkach przed i po obróbce cieplnej, a okresowo podczas przechowywania, oznaczano zawartość tiaminy metodą tiochromową oraz zmiany oksydacyjne na podstawie zawartości pierwotnych (liczba nadtlenkowa) i wtórnych (liczba anizydynowa) produktów utlenienia.

Wyniki. Zaobserwowano, że straty tiaminy w mięsie pasteryzowanym były wyższe (61-71\%) niż mięsie sterylizowanym (57-67\%). Dodatek utlenionego tłuszczu zwiększył straty tiaminy zarówno podczas procesu termicznego, jak i podczas przechowywania (do 23\%). Stwierdzono dużą zależność liniową pomiędzy stratami tiaminy a wskaźnikami utlenienia tłuszczu. Najmniejsze straty tiaminy ogólnej zaobserwowano w próbkach z dodatkiem świeżego smalcu. Dodatek przeciwutleniaczy (ekstraktu rozmarynu i hydrolizatu kazeiny) wpływał na zmniejszenie tych strat. Jednak ich efekt ochronny zależał od rodzaju obecnego tłuszczu. W próbkach z dodatkiem świeżego tłuszczu wyższe właściwości ochronne wobec tiaminy wykazywał ekstrakt rozmarynu (7-11\%), a w układach zawierających utleniony tłuszcz korzystniej wpływał hydrolizat kazeiny $(14 \%)$.

Wnioski. W celu zwiększenia stabilności tiaminy w pasteryzowanych lub sterylizowanych produktach mięsnych z dodatkiem tłuszczów należy zwrócić uwagę na wpływ rodzaju obecnego tłuszczu i jego stabilność oksydacyjną. Ponadto dodatek ekstraktu rozmarynu lub hydrolizatu kazeiny ma wpływ na zmniejszenie strat tiaminy, głównie poprzez spowolnienie utleniania obecnych tłuszczów.

Słowa kluczowe: procesy termiczne, mięso drobiowe, tiamina, przeciwutleniacze

For citation - Do cytowania

Szymandera-Buszka K., Hęś M., Waszkowiak K., Jędrusek-Golińska A., 2014. Thiamine losses during storage of pasteurised and sterilized model systems of minced chicken meat with addition of fresh and oxidized fat, and antioxidants. Acta Sci. Pol., Technol. Aliment. 13(4), 393-401. 